SiEgFried RAMLER, retired; 1809-935 Marine Drive, West Vancouver, British Columbia, Canada.

ERNEST WYNFORD REES, formerly Deputy Medical Director, Roffey Park Hospital, Sussex.
Sidney Raphael Shaw, retired; 22 Tennyson Street, Narborough, Leicester LE9 5FD.

Louss MAURICE Zinkin, Consultant Psychotherapist, St George's Hospital, London SW17 0QT.

Psychiatric Bulletin (1993), 17, 639-640

\title{
Miscellany
}

\section{Professor Hamid Ghodse}

Professor Ghodse, St George's Hospital, London, a Fellow of the College, has been elected President of the International Narcotics Control Board.

\section{Schizophrenia Research Award}

This bi-annual scientific award, amounting to US $\$ 25,000$, granted by the Janssen Research Council, Beerse, Belgium, under the auspices of the CINP (Collegium Internationale Neuro-Psychopharmacologicum) is open to any young investigator (less than 45 years old on 1 January of the year of the award) who has performed outstanding research in the area of the clinical neuroscience of schizophrenia at a university institute or other acknowledged scientific institution that is independent of the pharmaceutical industry. Further information: Dr Bernd Saletu, Department of Psychiatry/School of Medicine, University of Vienna, Währinger Gürtel 18-20, A-1090 Vienna, Austria.

\section{Annual Meeting 1993 audio cassettes}

Audio cassettes of the College's 1993 Annual Meeting are available from QED Recording Services Ltd., Lancaster Road, New Barnet, Herts EN4 8AS (telephone 081441 7722; fax 081441 0777). Mail order prices (including VAT and postage and packing): $£ 7.00$ per tape; $£ 295.00$ for complete set of tapes in presentation album.

\section{New publications}

The Association for the Advancement of Philosophy and Psychiatry (AAPP) in conjunction with the Royal College of Psychiatrists' Philosophy Group will begin publication of a new journal, Philosophy, Psychiatry, and Psychology (PPP) in 1994. This international journal, to be published by the Johns Hopkins University Press, will focus on philosophical aspects of psychiatry and clinical psychology and is now seeking manuscript submissions. Further information: Linda Muncy, Administrative Secretary, AAPP, Department of Psychiatry, The University of Texas Southwestern Medical Center, 5323 Harry
Hines Blvd., Dallas, TX 75235-9070, USA (telephone 01012146483390 ).

The Royal College of Nursing has recently published Guidelines for Assessing Mental Health Needs in Old Age. Further information: Pauline Ford, Royal College of Nursing, 20 Cavendish Square, London W1M 0AB (telephone 071409 3333).

A research paper Elderly Homeless People Sleeping on the Streets in Inner London: an exploratory study by Maureen Crane is available from the Age Concern Institute of Gerontology, King's College London, Cornwall House Annexe, Waterloo Road, London SE1 8TX, price $£ 7.00$ including postage and packing. Please enclose cheque with orders, made payable to King's College London.

The Mental Health Act Commission has published its first Practice Note which gives guidance on the administration under the Mental Health Act of Clozapine and other treatments requiring blood tests. Copies of the Practice Note can be obtained by sending a stamped addressed envelope to: Mental Health Act Commission, Maid Marian House, 56 Hounds Gate, Nottingham NG3 6BG.

Primary Health Care in London: Quantifying the Challenge has been published by the King's Fund Institute. It costs $£ 12.00$ and is available from Bournemouth English Book Centre, 9 Albion Close, Parkstone, Poole, Dorset BH12 3LL (telephone 0202 715555; fax 0202 715556).

Shared Care of Patients with Mental Health Problems. Report of a Joint Royal College Working Group is published as Occasional Paper 60 and is available from the Sales Office, Royal College of General Practitioners, 14 Princes Gate, Hyde Park, London SW7 1PU, price $£ 6.00$, including postage. (Telephone 071823 9698.)

\section{Call for papers}

There is a call for papers for a forthcoming special issue on Women's Mental Health to be published in 1994 in the Journal of Mental Health Administration 